\title{
Implementation of lean production in construction component manufacturing
}

\author{
Lauri Koskela $^{a}$ and Jukka Leikas ${ }^{b}$
}

aVTT Building Technology, P.O. Box 1801, 02044 VTT, Finland, e-mail: lauri.koskela@vtt.fi

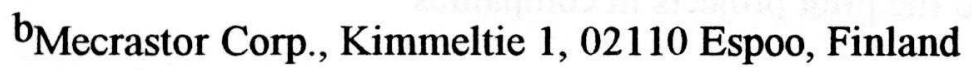

\begin{abstract}
This paper is based on a research project undertaken by a consultancy company, a research institute, and six construction component manufacturing firms. The goal was to draw up a methodology for initiating lean production activities in construction component manufacturing, and to verify the potential of lean production in this industry through practical experiments.

The resultant conceptual and methodological framework is outlined, and the implementation procedure is presented. Process improvement and redesign initiatives implemented by participating firms, along with related results and benefits, are analyzed. Finally, the feasibility and the significance of lean production in construction component manufacturing are discussed.
\end{abstract}

\section{INTRODUCTION}

Since 1991, the Finnish economy has experienced a deep recession. The volume of building construction in 1994 is less than half in comparison to 1990. Practically all organizations in the construction industry have been forced to downsize. Also the construction component industry has been severely hit by the recession. Thus, there are great pressures to raise profitability and competitiveness, but rather little money to invest for these purposes. "Lean production", promising significant benefits in short term and with modest funding, looks like an ideal solution in this situation.

This was the background of the research project "Lean construction component manufacturing", undertaken by Mecrastor Corp. (consultancy company), VTT Building Technology, and six construction component manufacturing firms. The objective was to draw up a methodology for initiating lean production activities in construction component manufacturing, and to verify the potential of lean production in this industry through practical experiments.

Among the firms, there was both small and medium sized firms as well as larger companies. The participating firms and the product lines selected for experimentation were as follows: 
- Gyproc Ltd

- Lujabetoni Ltd

- Metsäpuu Ltd

- Novart Ltd

- Parma Ltd

- Rakennusbetoni- ja elementti lightweight concrete elements for partitioning walls Ltd

The division of work was as follows. The theoretical and conceptual framework of lean production was created by VTT Building Technology. The methodology was set up by Mecrastor and VTT Building Technology. The consultants of Mecrastor provided methodological training and facilitated the pilot projects in companies.

\section{LEAN PRODUCTION}

The conceptual framework of lean production has been outlined in earlier work $[1,2,3]$. In the following, we summarize the main features. The underlying idea was to simplify and unify the conceptual and methodical framework so, that it can be used without difficulty even in small and medium sized firms.

\subsection{Conceptual framework of lean production}

The conceptual framework of lean production combines three different views of production and operations:

- material or information is converted (traditional view)

- material or information flows (Just-in-Time view)

- value is generated through fulfilment of customer requirements (quality view).

Thus, production is seen as flow processes, which are composed of

- conversion activities

- flow activities: moving, waiting and inspection

- customers, for which value is generated.

The intrinsic flow process goals are to decrease process cost and duration and to increase value for the customers. The value consists of two components: product performance and freedom from defects (conformance to specification). Value has to be evaluated from the perspective of the next customer(s) and the final customer. In opposition to cost and duration, it is difficult, often impossible to measure the absolute value. However, for practical application, measuring the relative value often suffices; for example the value loss in relation to the best practice value or theoretically best value.

An important distinction is based on the insight that not all activities generate value. In flow processes, we distinguish value-adding and non value-adding activities : 
- Value-adding activity: Activity that converts material and/or information towards that which is required by the customer.

- Non value-adding activity (also called waste): Activity that takes time, resources or space but does not add value.

Note that conversion activities are usually value adding, but not all. Similarly, flow activities are usually, but not always, non value adding.

The improvement of non value adding activities should be focused on their reduction or elimination, whereas value adding activities have to be made more efficient.

Thus, we have three options for improving production:

- Reducing the costs (and duration) of value adding activities through increased efficiency.

- Reducing the costs (and duration) of non value adding activities (waste), through elimination of these activities.

- Reducing the value loss.

The potential of lean production is embodied in the two later options; the first one has been customarily used.

\subsection{Principles and methods of lean production}

Given that we have to reduce waste and value loss, what are the principles and methods to do this? A number of principles and methods exist for controlling, designing and improving flow processes [1]. They are closely related to the respective cause of waste and value loss. Regarding waste, its causes and corresponding principles are summarized in Table 1.

Table 1. Causes of waste and corresponding lean principles or methods

Cause of waste

Hierarchical organization

Process not in control (excessive variability)

Waste not recognized, not measured

Long and complicated information and material Simplification flows

Process rigidities

Suboptimization

Confusion and disorder
Lean principle or method

Process oriented, team based, flat organization

Reduction of variability

Process charting for identification of non value adding activities; compression of cycle times

Increased flexibility

Focus on whole processes

Visual management 


\subsection{Measurements in lean production}

Given that the implementation of lean principles is underway, how do we know that we are making progress? Even if it is not practical to measure the total waste in the process, it is possible to use indirect or partial measures of waste (Figure 1). The same applies for loss of value.

\section{METHODS OF IMPLEMENTATION}

Each firm organized a team to carry out the project. In most firms, there were worker participation in the team. In all cases, there were support from the top management. The work was directed and carried out by the team and facilitated by the consultant. The progress in each firm was reported and discussed in joint meetings where all involved organizations participated. The experimental implementation in firms was carried out from October 1993 to June 1994.

The experimentation wàs positioned by the firms in different ways, according to their situation. Some firms used the project for learning and trialling the lean methodology, some for augmenting TQM activities. However, in some firms the project was considered as the main thrust regarding the improvement of the product line in question.

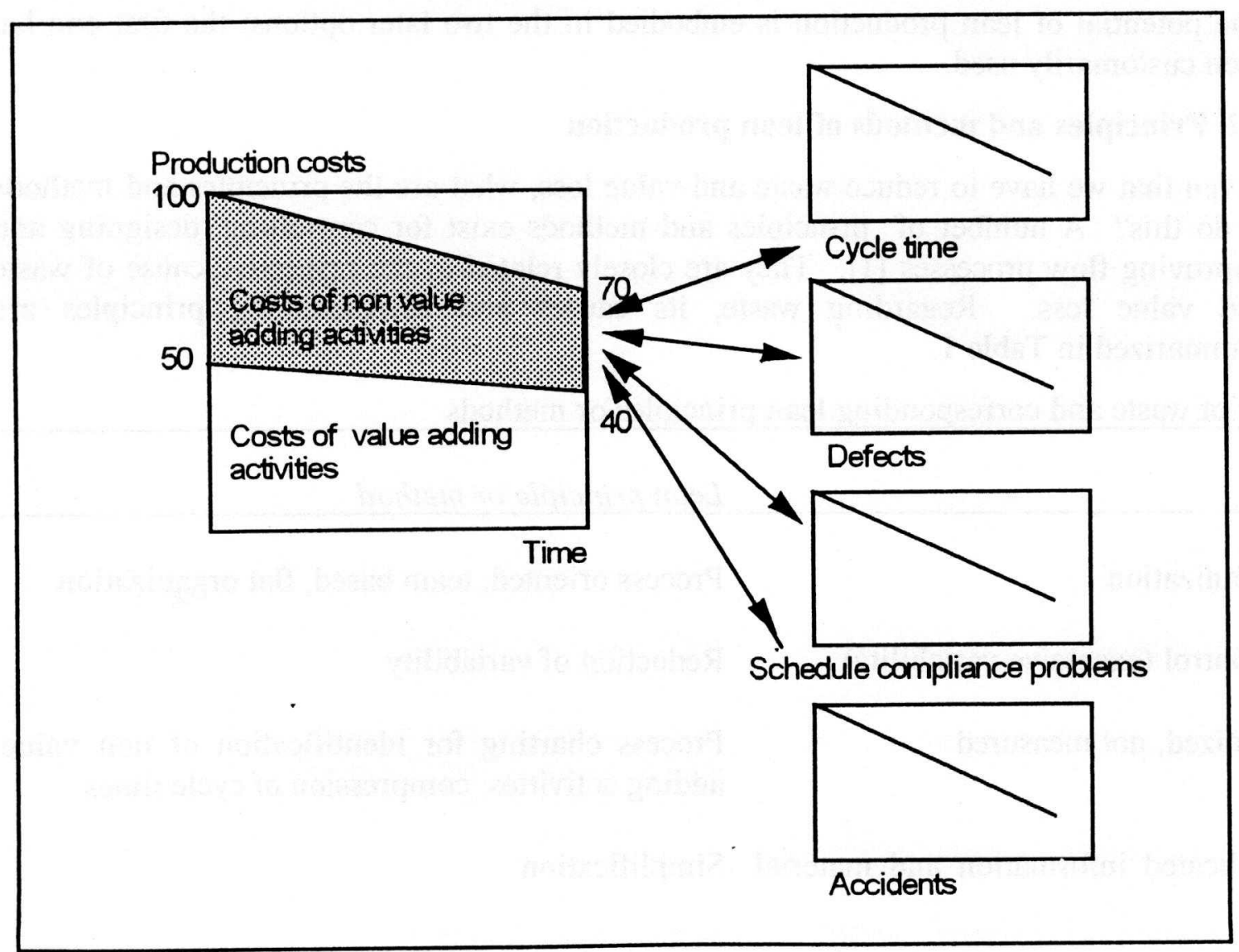

Figure 1. It is not practical to measure the total costs of non value-adding activities, however, indirect or partial measures may be used. 
The implementation started through selection of major macro-processes as subjects for experimentation. These were further divided into micro-processes, which could be analyzed separately. The processes were then charted and measured: especially the waste (rework, material waste, idle time due to waiting, etc.) and the value loss were analyzed and their causes were investigated. Improvement goals were stated and corresponding action was planned, aiming at a redesigned process or improvement of the existing process.

\section{FINDINGS}

\subsection{Concepts and methods of lean production}

In general, the conceptual and methodological approach worked well. A number of difficulties were met:

- The distinction value adding activity/non value adding activity was perceived as too simplistic or harsh. Some people were offended when a part of their tasks was labelled as waste. Thus, a third category was introduced: activities without value added. These are activities that are essentially wasteful but necessary under current operating procedures [4].

- Methods taught, analysis forms prepared, etc. were not followed in detail, but rather selectively. However, this can not be considered as a major problem, because internalization of the main concepts of the approach proved to be much more important than strict observance to step-by-step guidelines.

Making waste visible (by flow charting or measurements) turned out to be the most important single feature of the conceptual and methodological approach. It motivated all, both workers and management, to think creatively about new solutions and to accept changes to time-honoured practices.

\subsection{Analysis of the current situation}

Most firms focused on waste, rather than value loss, when analyzing the current situation. In all cases waste, that earlier had existed unobserved, was detected and made visible.

Typically, only $20 \%$ of all steps in order processing or production were evaluated as value adding. In order processing, a major share of working time, $25-40 \%$, was allocated to finding missing information, rework or other non value adding activity. Similar figures were found in production.

The major internal causes for waste were as follows:

- The traditional organizational model, leading to fragmented and long work flows, and narrow tasks.

- Layout problems: tasks or functions requiring communication or material transfer are located so that the their distance is long.

A part of waste was caused by the specific features of the customer industry, construction. Some examples: 
- There is a tendency to place construction component orders with missing information, obviously due to incompleteness of design; the amount of order changes is also relatively high

- Due to the generally poor dimensional accuracy in construction, one firm has to make measurements on site and produces then the components according to these, instead of relying on measures as presented in drawings.

- Traditionally, design and production of buildings are carried out by separate organizations; designers lack knowledge on manufacturability and constructability.

\subsection{Improvement initiatives}

An overview on the improvement initiatives is given in Table 2. Besides the actions presented, there were numerous instances where waste could be eliminated through minor, immediate changes.

The most extensive changes were carried out by Lujabetoni and Parma. These are described in more detail.

At Lujabetoni, the pilot project stimulated the following changes:

- Two organizational levels were abolished.

- Production was organized as self-directed teams of $6-8$ persons.

- Purchasing was simplified: the teams order directly materials from suppliers.

- The role of foremen was changed to that of facilitator and trainer.

- Sales strategy was changed: sales and internal design department work as a team at project offering stage.

- Several changes, required by users, to information systems were realized.

- Continuous measurement of sales and production was started: on each Monday, the profit of the previous week is disclosed (to all) and compared with the target

- The practice of having 2-3 men making repairs to facade elements on site - all over the country - was abolished (instead, the quality of elements delivered from the factory was increased)

At Parma, the changes were as follows:

- Production was organized as self-directed teams of $4-6$ persons. The team takes care of the majority of assembling operations of a bathroom. It also handles short term planning. A member of the team goes to the site to carry out the hand-over inspection together with the contractor.

- The role of the designer was extended to that of a project leader $($ order $=$ project). The project leader takes the overall responsibility for the smooth progress and timely delivery of the order. He becomes involved as early as possible, already when customer requirements are charted. He is in regular, direct contact to each team that is producing bathrooms for his project. 
Clearly most initiatives addressed internal causes of waste; it is more difficult to influence external causes, especially those originated by customers. However, one firm introduced a policy of not forwarding an order to production planning before all necessary specifications are delivered by the customer (the complete kit concept [5]). This proved to be effective.

Table 2. Overview on process redesign/improvement implemented and related results and benefits.

\begin{tabular}{|c|c|c|c|}
\hline Firm & Process analyzed & Process redesign and improvement & $\begin{array}{l}\text { Results } \\
\text { benefits }\end{array}$ \\
\hline Gyproc Ltd & $\begin{array}{l}\text { After-treatment of } \\
\text { boards (cutting, } \\
\text { handling, storing, } \\
\text { packaging) }\end{array}$ & $\begin{array}{l}\text { Layout changes and other } \\
\text { operational changes aiming at } \\
\text { streamlining of material flows }\end{array}$ & $\begin{array}{l}\text { Implementatio } \\
\text { n still } \\
\text { underway. }\end{array}$ \\
\hline $\begin{array}{l}\text { Lujabetoni } \\
\text { Ltd }\end{array}$ & $\begin{array}{l}\text { Sales-order- } \\
\text { production- } \\
\text { delivery process }\end{array}$ & $\begin{array}{l}\text { Team based, flat organization has } \\
\text { been implemented. Information and } \\
\text { material flows have been } \\
\text { streamlined. }\end{array}$ & $\begin{array}{l}\text { Productivity, } \\
\text { quality, } \\
\text { profitability } \\
\text { and worker } \\
\text { participation } \\
\text { have clearly } \\
\text { increased. }\end{array}$ \\
\hline $\begin{array}{l}\text { Metsäpuu } \\
\text { Ltd }\end{array}$ & $\begin{array}{l}\text { Sales-order- } \\
\text { delivery process }\end{array}$ & $\begin{array}{l}\text { Technical changes: collocation of } \\
\text { key persons, EDI. Operational } \\
\text { changes: objectives and incentives } \\
\text { for teams. Improvement of standard } \\
\text { routines and related training. }\end{array}$ & $\begin{array}{l}\text { Identification } \\
\text { of } \\
\text { improvement } \\
\text { potential is } \\
\text { evaluated by } \\
\text { the firm as the } \\
\text { most } \\
\text { important } \\
\text { result. }\end{array}$ \\
\hline Novart Ltd & $\begin{array}{l}\text { Order-delivery } \\
\text { process }\end{array}$ & $\begin{array}{l}\text { Various operational changes } \\
\text { implemented: parametric cost } \\
\text { estimation for prebids, streamlining } \\
\text { of the flow of order information to } \\
\text { production planning. Decision made } \\
\text { on redesign of the total information } \\
\text { flow, including the elimination of } \\
\text { invoicing as a separate task. }\end{array}$ & $\begin{array}{l}\text { Improvement } \\
\text { of customer } \\
\text { service, } \\
\text { reduction of } \\
\text { errors related } \\
\text { to order } \\
\text { information, } \\
\text { increased } \\
\text { productivity. }\end{array}$ \\
\hline
\end{tabular}




\begin{tabular}{|c|c|c|c|}
\hline Parma Ltd & $\begin{array}{l}\text { Order- } \\
\text { production- } \\
\text { delivery process }\end{array}$ & $\begin{array}{l}\text { Team based production organization } \\
\text { has been implemented. The role of } \\
\text { designers has been changed to that } \\
\text { of project leader (each order is a } \\
\text { project). }\end{array}$ & $\begin{array}{l}\text { Production } \\
\text { cycle time has } \\
\text { decreased, } \\
\text { productivity } \\
\text { increased, } \\
\text { workers } \\
\text { participate } \\
\text { actively in } \\
\text { improvement. }\end{array}$ \\
\hline $\begin{array}{l}\text { Rakennus- } \\
\text { betoni- ja } \\
\text { elementti } \\
\text { Ltd }\end{array}$ & $\begin{array}{l}\text { Order- } \\
\text { production- } \\
\text { delivery- } \\
\text { installation } \\
\text { process }\end{array}$ & $\begin{array}{l}\text { The product offered to the customer } \\
\text { is being changed from elements to } \\
\text { ready partitioning walls; various } \\
\text { standard routines for the order- } \\
\text { delivery-installation process were } \\
\text { developed. }\end{array}$ & $\begin{array}{l}\text { Sales process } \\
\text { will change; } \\
\text { implementatio } \\
\text { n still } \\
\text { underway. } \\
\text { Better service } \\
\text { to customer } \\
\text { and reduction } \\
\text { of waste are } \\
\text { anticipated to } \\
\text { be the most } \\
\text { important } \\
\text { results. }\end{array}$ \\
\hline
\end{tabular}

\subsection{Results and benefits}

In all firms, the results of the pilot project were evaluated as good or excellent. This is reflected in the comments by firms on results presented in Table 2 . In the following, more detailed information is presented for the two firms analyzed above.

Lujabetoni Ltd. reported the following results and benefits:

- The capacity (average production volume) has increased $20 \%$ due to lean initiatives.

- The costs of goods sold (COGS) have decreased 5 - $10 \%$.

- Claims and quality costs in general have decreased essentially.

- The atmosphere in the factory is excellent.

At Parma Ltd., results and benefits are as follows:

- Production is organized into 19 tasks; in the earlier situation, there were 36 tasks. It is estimated that this alone will result in saving $5 \%$ of the working time (consumed earlier in waiting).

- The number of different drawings made for production was halved.

- Production cycle time has decreased. 
- Workers are motivated and participate actively in improvement.

In both of these firms, the lean principles are being transferred to other production lines, and the improvement of the piloted production line is continuing.

In general, the results exceeded the expectations of the participants of the project.

\section{CONCLUSIONS}

This experimental implementation of lean production clearly shows, that this approach can provide significant and rapid benefits in construction component manufacturing. It is also understood that the potential of waste (and value loss) elimination was by no means exhausted in these experiments: there is ample room for further improvement.

Thus, lean production is applicable and worthwhile in construction component manufacturing. In this industry, the same internal causes for waste, as in other manufacturing industries, exist. However, beyond that, the erratic and undisciplined nature of the customer industry, construction, provides an additional source of waste.

For manufacturing related causes of waste, the methods and techniques developed in other industries are applicable also in construction component manufacturing. However, regarding construction related causes of wastes, new solutions are needed. Experimentation, development and research are thus required.

The improvement potential detected gives support to the argument that in industrialization of construction, poorly controlled design, fabrication and site processes have often consumed the theoretical benefits to be gained from industrialization [1]. It is not enough to change construction to look like (traditional) manufacturing, rather the total design-fabrication-erection process should be designed and improved so that real and significant benefits emerge.

It is customary to view information technology and automation as the major means for improving efficiency in construction component manufacturing. These results rather support the thesis [6]: "In work flows in construction, it is more profitable to initiate process improvement activities than to automate parts of the present work flow". Thus, both lean production and information technology/automation should be seen as major improvement approaches, which complement each other.

\section{ACKNOWLEDGEMENTS}

The described project was funded by Technology Development Centre, Mecrastor Corp. and the six participating companies. The project was initiated and organized in cooperation with the Finnish Association of Construction Product Industries and VTT Building Technology. 


\section{REFERENCES}

1 Koskela, L. 1992. Application of the New Production Philosophy to Construction. Technical Report \# 72. Center for Integrated Facility Engineering. Department of Civil Engineering. Stanford University. 75 p.

2 Koskela, L. 1993. Lean Production in Construction. The 10th International Symposium on Automation and Robotics in Construction (ISARC), Houston, Texas, U.S.A., 24 - 26 May, 1993. Elsevier. Pp. 47 - 54.

3 Koskela, Lauri \& Sharpe, Ron. 1994. Flow process analysis in construction. The 11th International Symposium on Automation and Robotics in Construction (ISARC), Brighton, U.K., 24 - 26 May, 1994. Elsevier. Pp. 281 - 287.

4 Monden, Yasuhiro. 1994. Toyota Production System. Second Edition. Chapman \& Hall, London. 423 p.

5 Ronen, B. 1992. The complete kit concept. Int. J. Prod. Res., Vol. 30, No. 10, $2457-2466$.

6 Koskela, Lauri. 1992. Process Improvement and Automation in Construction: Opposing or Complementing Approaches? The 9th International Symposium on Automation and Robotics in Construction, 3 -5 June 1992, Tokyo. Proceedings. Pp. 105-112. 